\title{
Profitability and efficiency of fertilization in a corn/ soybean/corn system in a Latosol with improved fertility
}

\author{
Clério Hickmann ${ }^{1}$ \\ Álvaro Vilela de Resende ${ }^{2}$ \\ Carlos Alberto Silva ${ }^{3}$ \\ Julian Junio de Jesus Lacerda ${ }^{4}$ \\ Silvino Guimarães Moreira ${ }^{5}$ \\ Otávio Prates Conceição 6
}

\section{Abstract}

Currently, there are some doubts regarding fertilization dimensioning that aims at a high grain yield in soils with improved fertility in a crop rotation system. Thus, the objective of this study was to evaluate the yield and profitability resulting from different combinations of NPK fertilization and the efficiency of these nutrients in sequential crops of corn/soybean/corn, in a Latosol with improved fertility, in a farm located in the region of Campo das Vertentes, Minas Gerais State, Brazil. Four doses of sowing fertilization and topdressing were compared, corresponding to approximate proportions of $25,50,100$ and $150 \%$ of the doses usually applied by farmers. Nutrients sources varied according to the inputs used in the farm for each crop. In a soil with improved fertility, corn is more responsive to fertilization than soybean, with higher grain yield gains associated with $N$ and $K$ supply, while $P$ is less limiting. The most profitable nutrients combination for this system involves increasing the amounts of $\mathrm{N}$ and $\mathrm{K}$ and reducing the amount of $\mathrm{P}$ in relation to the standard fertilization employed on the farm, providing a $14.3 \%$ higher profit and higher average nutrient use efficiency.

Keywords: Fertilizer use efficiency. Crop rotation. High grain yield. High-investment agriculture.

\section{Introduction}

The intensive use of technologies in grain crops, such as the development of new cultivars, application of liming and fertilizers, mechanization, and crop rotation, has made some regions of Minas Gerais State, Brazil stand out among the areas with the greatest productive potential in the country. Recently, the mesoregion of Campo das Vertentes has been considered as one of the most important grain production centers in the state.

In this region, the use of early soybean cultivars with indeterminate growth habit is a promising option for rotation with corn under no-tillage system (NTS) and makes it possible the use of other crops in the second crop. In addition, soybean is associated with nitrogen-fixing bacteria $(\mathrm{N})$,

\footnotetext{
Universidade do Oeste de Santa Catarina, professor. clerioh@gmail.com. CEP 89900-000, São Miguel do Oeste, SC, Brasil.

Embrapa Milho e Sorgo, pesquisador. alvaro.resende@embrapa.br.

Universidade Federal de Lavras, professor. csilva@dcs.ufla.br.

Universidade Federal do Piaui, professor. julianlacerda@gmail.com.

Universidade Federal de Lavras, professor. silvinomoreira@dag.ufsj.br.

6 Universidade Federal de Lavras, estudante de Mestrado. otavio_prates@hotmail.com.
} 
aggregating this nutrient to the straw, which, when decomposed, supplies the $\mathrm{N}$ to the successive crop (ALMEIDA et al., 2008; TORRES; PEREIRA; FABIAN, 2008). Long-term studies have demonstrated higher corn yield in rotation with soybeans, even under restricted nutrients availability, when compared with monocultures with adequate nutritional supply (KATSVAIRO; COX, 2000; STANGER; LAUER, 2008).

The advance in the consolidation of production systems in Brazilian soils was only possible with the introduction of soil management practices that involve acidity amendments and fertilizer application to improve fertility. By prioritizing soil fertility improvement and maintenance fertilization throughout successive crops, the residual fertilizer has generated considerable nutrients reserves, particularly in clayey soil (ALMEIDA et al., 2005; GATIBONI et al., 2007). In this scenario, the introduction of NTS provided an additional advantage, including the greater conservation and possible increase of the stocks of soil organic matter, benefiting the chemical, physical, and biological characteristics of the soil. These factors have increased the productive potential of growing environments (RESENDE et al., 2012). Production stands with clayey soils usually present levels of phosphorus (P - Mehlich1) and potassium (K) above 15 and $120 \mathrm{mg} \mathrm{dm}^{-3}$, respectively, which characterizes high fertility, very close to that of corn production areas in the United States. Therefore, soil analysis interpretation and fertilization recommendation become more complex due to the lack of research data on the response of the crops to the application of fertilizers aiming at high yield in these soils with improved fertility. Several farmers simply increase fertilization with fixed NPK formulas, which can result in low fertilizer use efficiency.

Yield expectation, previous crop history, or previous cover crop, soil organic matter content, and the crops used in the crop rotation system are the criteria for the definition of the $\mathrm{N}$ doses to be applied to crops (AMADO; MIELNICZUK; AITA, 2002). Yield responses of soils with P and K content above the critical level are not expected to generate economic gains for corn and soybean due to the increase in fertilizer doses during maintenance fertilization. It is enough to replace the amount of nutrients exported with the crop (SOUSA; LOBATO, 2004; PAULETTI et al., 2010). According to Alvarez et al. (1999), the critical P and K levels in clayey soils of Minas Gerais are 12 and $70 \mathrm{mg}$ $\mathrm{dm}^{-3}$, respectively.

Therefore, more specific geological studies are required to identify fertilization levels that reconcile high grain yield, fertilizer use efficiency and soil fertility maintenance over time. The objective of this work was to evaluate the yield and profitability of different combinations of NPK fertilization and nutrient use efficiency in sequential corn/soybean/corn crops in a clayey Latosol, in a farm located in the region of Campos das Vertentes, Minas Gerais State, Brazil.

\section{Material and methods}

The study was carried out at Fazenda Santa Helena, located in the municipality of Nazareno,

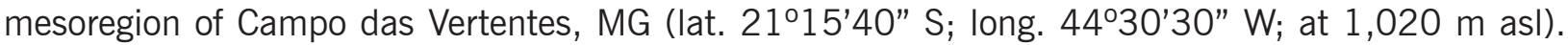
The soil was classified as a Clayey Dystrophic Red-Yellow Latosol. Table 1 presents the soil chemical attributes and texture, according to Silva (2009). The degree of soil fertility at the beginning of the experiment was considered as intermediate to high, according to the classification of Alvarez et al. (1999). The area had been cultivated for about twenty years and the history of the last ten years is characterized by high technological investment. The soil is managed under no-tillage system over consecutive corn crops, with fallow in the offseason. In this period, only in one year (2007) sunflower was cultivated as a second crop. 
Table 1. Chemical attributes, texture, and density of the Red-Yellow Latosol, at the 0 to $20 \mathrm{~cm}$ depth layer, before the experiment implantation.

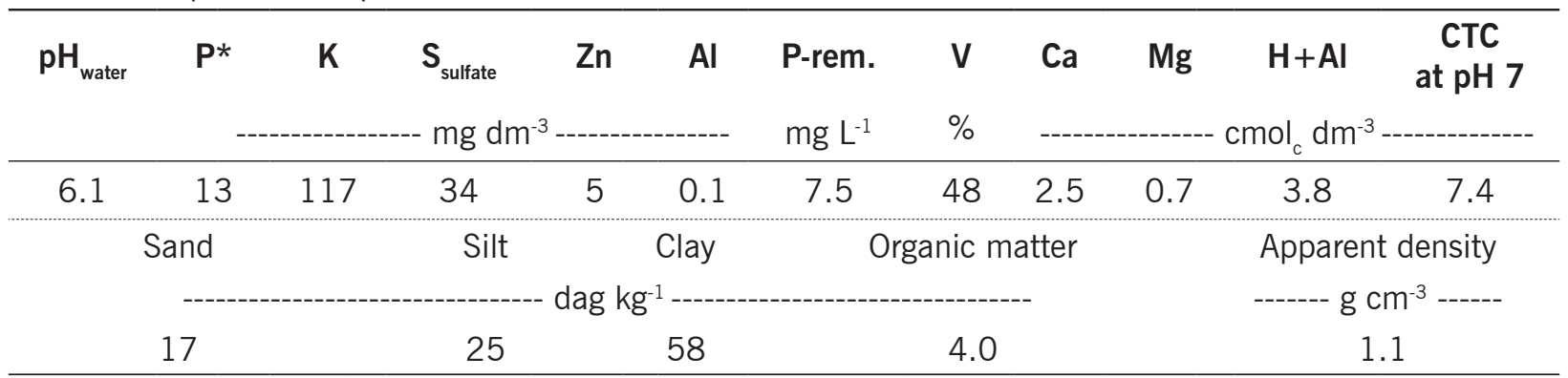

* Extracted with the Mehlich-1 solution. The methodologies used for the analysis of all attributes were based on Silva (2009).

Source: Elaborated by the authors (2017)

Three crops were evaluated in the corn/soybean/corn rotation system, under rainfed conditions, in the 2010/2011, 2011/2012 and 2012/2013 agricultural years, with fallow between crops. Cultivars Down 2B587 Hx, Nidera NA5909 RR, and Pioneer P30F53 H were used for the respective crops, with a spacing of $0.6 \mathrm{~m}$ between rows. Sowing was carried out on 11/03/2010 (corn), 10/21/2011 (soybean) and 15/10/2012 (corn). Phytosanitary treatments were performed when necessary, according to the farm's protocol. The estimated plant populations in the respective crops were 73,000, 380,000 and 75,000 plants ha-1.

The experiment consisted of a randomized block design with three replications, in a $4 \times 4$ factorial scheme, combining the application of fertilizers at four doses in sowing fertilization and four doses in topdressing, as described in Table 2. In the sowing fertilization, nutrients were applied in the furrow in the plots, while topdressing treatments were applied in strips between rows, constituting the subplots. The reference for the definition of fertilizer doses was the fertilization typically used on the farm, which corresponded to the third dose (sowing and topdressing) of the interval tested in each crop (Table 2). The other doses were used to evaluate crop's response to fertilizer increment/reduction practiced on the farm. The sources of nutrients varied in each crop, depending on the fertilizers used by the farmer. Topdressing was carried out at the V3-V4 stage of corn and V2 stage of soybean. The subplots consisted of nine $10 \mathrm{~m}$ rows. Yield was evaluated by harvesting three $4 \mathrm{~m}$ rows in the subplots central area $\left(7.2 \mathrm{~m}^{2}\right)$. 
Table 2. Amounts of fertilizers applied at sowing (SOW) and topdressing (TOP) and total nutrients supplied to each crop, according to the fertilization treatments*.

\begin{tabular}{|c|c|c|c|c|c|c|c|c|}
\hline \multicolumn{3}{|c|}{ Corn - 2010/2011 } & \multicolumn{3}{|c|}{ Soybean - 2011/2012 } & \multicolumn{3}{|c|}{ Corn - 2012/2013 } \\
\hline sow & TOP & & sow & TOP & & sow & TOP & \\
\hline $\begin{array}{c}\text { Fertilizer } \\
\text { NPK } \\
10-30-10\end{array}$ & $\begin{array}{l}\text { Fertilizer } \\
\text { NPK } \\
30-00-20\end{array}$ & $\begin{array}{c}\text { Total } \\
\mathrm{N}-\mathrm{P}_{2} \mathrm{O}_{5}-\mathrm{K}_{2} \mathrm{O}\end{array}$ & $\begin{array}{c}\text { Fertilizer } \\
\text { NPK } \\
02-30-10\end{array}$ & $\begin{array}{c}\text { Fertilizer } \\
\mathrm{KCl}\end{array}$ & $\begin{array}{c}\text { Total } \\
\mathrm{N}-\mathrm{P}_{2} \mathrm{O}_{5}-\mathrm{K}_{2} \mathrm{O}\end{array}$ & $\begin{array}{c}\text { Fertilizer } \\
\text { NPK } \\
18-38-00\end{array}$ & $\begin{array}{c}\text { Fertilizer } \\
\text { NPK } \\
22-00-20\end{array}$ & $\begin{array}{c}\text { Total } \\
\mathrm{N}-\mathrm{P}_{2} \mathrm{O}_{5}-\mathrm{K}_{2} \mathrm{O}\end{array}$ \\
\hline & & & & $\mathrm{kg} \mathrm{ha}{ }^{-1}$ & & & & \\
\hline 0 & 0 & $0-0-0$ & 0 & 0 & $0-0-0$ & 0 & 0 & $0-0-0$ \\
\hline 0 & 210 & $63-0-42$ & 0 & 25 & $0-0-15$ & 0 & 300 & $66-0-60$ \\
\hline 0 & 420 & $126-0-84$ & 0 & 50 & $0-0-30$ & 0 & 600 & $132-0-120$ \\
\hline 0 & 630 & $189-0-126$ & 0 & 75 & $0-0-45$ & 0 & 900 & 198-0-180 \\
\hline 240 & 0 & $24-72-24$ & 193 & 0 & $4-58-19$ & 155 & 0 & $28-59-0$ \\
\hline 240 & 210 & $87-72-66$ & 193 & 25 & $4-58-34$ & 155 & 300 & $94-59-60$ \\
\hline 240 & 420 & 150-72-108 & 193 & 50 & $4-58-49$ & 155 & 600 & $160-59-120$ \\
\hline 240 & 630 & $213-72-150$ & 193 & 75 & $4-58-64$ & 155 & 900 & $226-59-180$ \\
\hline 386 & 0 & $39-116-39$ & 315 & 0 & $6-95-32$ & 316 & 0 & $57-120-0$ \\
\hline 386 & 210 & 102-116-81 & 315 & 25 & $6-95-47$ & 316 & 300 & $123-120-60$ \\
\hline 386 & 420 & $165-116-123$ & 315 & 50 & $6-95-62$ & 316 & 600 & $189-120-120$ \\
\hline 386 & 630 & 228-116-165 & 315 & 75 & $6-95-77$ & 316 & 900 & $255-120-180$ \\
\hline 570 & 0 & $57-171-57$ & 485 & 0 & $10-146-49$ & 462 & 0 & $83-176-0$ \\
\hline 570 & 210 & 120-171-99 & 485 & 25 & $10-146-64$ & 462 & 300 & $149-176-60$ \\
\hline 570 & 420 & $183-171-141$ & 485 & 50 & $10-146-79$ & 462 & 300 & $215-176-120$ \\
\hline 570 & 630 & $246-171-183$ & 485 & 75 & $10-146-94$ & 462 & 900 & $281-176-180$ \\
\hline
\end{tabular}

*The third dose used in sowing fertilization and topdressing for each crop corresponds to the dose used on the farm.

Source: Elaborated by the authors (2017)

Grain yield was determined by adjusting the moisture content to $130 \mathrm{~g} \mathrm{~kg}^{-1}$. Yield data of each crop were subjected to analysis of variance, using the SISVAR software (FERREIRA, 2011). Yield regression analyses and the cumulative responses of the three crops were performed according to the nutrient doses applied at sowing and topdressing for each crop. Maximum technical efficiency (DMTE) and maximum economic efficiency (DMEE) doses of fertilizer were estimated. DMEE was obtained considering the amount of fertilizer that provided grain yield corresponding to $90 \%$ of the maximum yield (WENDLING et al., 2008). The efficiency of the use of the nutrients applied as fertilizers was calculated for each crop, also considering the cumulative data, according to the following equation (FAGERIA; SANTOS; CUTRIM, 2007): NUE = [YWN - YWON] / ANA; at which NUE = nutrient use efficiency $\left(\mathrm{kg} \mathrm{kg}^{-1}\right), \mathrm{YWN}=$ grain yield with the nutrient $(\mathrm{kg}), \mathrm{YWON}=$ grain yield without the nutrient $(\mathrm{kg})$, and $A N A=$ amount of nutrient applied (kg).

The comparative economic evaluation of the fertilization treatments used the operational production cost of the farm, considering the variations of costs related to the doses of fertilizers. Fixed costs were not included in the calculations. The revenue was calculated based on the yield per treat- 
ment and the market price of the grains. The profit was obtained by the difference between the gross revenue and the final cost per treatment. All the calculations were based on the basic operational production cost per hectare of the farm in the 2012/2013 agricultural year, which was $\mathrm{R} \$ 1,964.00$ for corn and $\mathrm{R} \$ 1,569.00$ for soybean, not including the costs of fertilizers. These costs were determined based on the prices of regional suppliers in July 2013 , being $R \$ 1,312.00 ; R \$ 1,238.70 ; R \$$ $1,210.00 ; \mathrm{R} \$ 1,380.00 ; \mathrm{R} \$ 1,120.00 ; \mathrm{R} \$ 1,326.00$ per ton, respectively, for the fertilizers NPK 10-30-10, NPK 30-00-20, NPK 02-30-10, NPK 18-38-00, NPK 22-00-20, and potassium chloride (KCI). Revenues were calculated based on prices quotes of July 2013 , which were $R \$ 65.23$ and $\mathrm{R} \$ 24.22$ per bag (60 kg) for soybean and corn, respectively. As a reference, the US dollar exchange rate on July 25, 2013 was R\$2,251 (CENTRO DE ESTUDOS AVANÇADOS EM ECONOMIA APLICADA - ESCOLA SUPERIOR DE AGRICULTURA LUIZ DE QUEIRÓZ - CEPEA/ESALQ, 2013).

\section{Results and discussion}

In the three crops of the experiment, no statistically significant interaction was observed between sowing fertilization and topdressing for grain yield (Table 3). Significant isolated effects were observed in the sowing fertilization and topdressing for the two corn crops and only in the topdressing for the soybean crop.

Table 3. Summary of analysis of variance for grain yield in function of fertilization doses applied at sowing and topdressing in corn/soybean/corn rotation.

\begin{tabular}{lcccc}
\hline & & \multicolumn{3}{c}{ Mean square } \\
\cline { 3 - 5 } Source of variation & DF & Corn & Soybean & Corn \\
& & $\mathbf{2 0 1 0 / 2 0 1 1}$ & $\mathbf{2 0 1 1 / 2 0 1 2}$ & $\mathbf{2 0 1 2 / 2 0 1 3}$ \\
\hline Block & 2 & 57,911 & 227,756 & 41,475 \\
Fertilizer doses at sowing (SOW) & 3 & $4,274,885^{*}$ & $708,589^{\text {ns }}$ & $12,170,035^{*}$ \\
Error 1 & 6 & 218,209 & 154,208 & 602,712 \\
Fertilizer doses in topdressing (TOP) & 3 & $35,241,145^{*}$ & $575,309^{*}$ & $22,571,806^{*}$ \\
SOW x TOP & 9 & $3,700,81^{\text {ns }}$ & $36,214^{\text {ns }}$ & $735,078^{\text {ns }}$ \\
Error 2 & 24 & 176,872 & 82,411 & 475,828 \\
Total & 47 & - & - & - \\
CV 1 (\%) & - & 5.0 & 11.1 & 6.5 \\
CV 2 (\%) & - & 4.5 & 8.1 & 5.8 \\
\hline
\end{tabular}

* Significant at $5 \%$ probability by the $\mathrm{F}$ test. ${ }^{\text {ns }}$ not significant. SOW $=$ NPK doses applied at sowing fertilization. $\mathrm{TOP}=\mathrm{NK}$ and $\mathrm{K}$ doses applied at topdressing for corn and soybean, respectively.

Source: Elaborated by the authors (2017)

In general, significant yield was reported even in the treatments without sowing fertilization or topdressing in the three crops evaluated in this study (Figure 1), confirming the existence of a substantial soil nutrient stock (Table 1 ). No water restriction was reported during the crop cycle; rainfall was well-distributed over the seasons of the experiment.

In absolute terms, corn yield in the 2010/2011 agricultural year ranged from 5,810 to 11,573 $\mathrm{kg} \mathrm{ha}^{-1}$, depending on the combination of sowing fertilization and topdressing treatments. The lowest yield was reported for the treatment without any fertilization, even though the value was above the 
national mean estimated for the crop $\left(4,100 \mathrm{~kg} \mathrm{ha}^{-1}\right)$ (COMPANHIA NACIONAL DE ABASTECIMENTO - CONAB, 2013), confirming the good soil fertility resulting from previous fertilization in the area. However, results revealed a linear increase in yield in function of the NPK doses applied as sowing fertilization and quadratic response to NK doses applied as topdressing (Figures $1 A$ and $1 B$ ).

Figure 1. Corn grain yield in the 2010/2011 (A and B) and 2012/2013 ( $E$ and F) agricultural years, and soybean grain yield in the 2011/2012 (C and D) agricultural year, in function of sowing fertilization and topdressing. **Significant at $1 \%$ probability.

A.

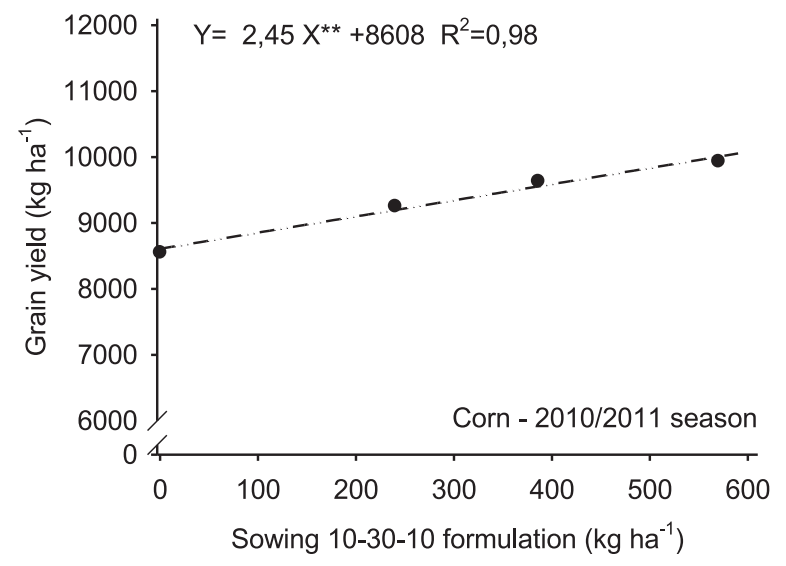

C.

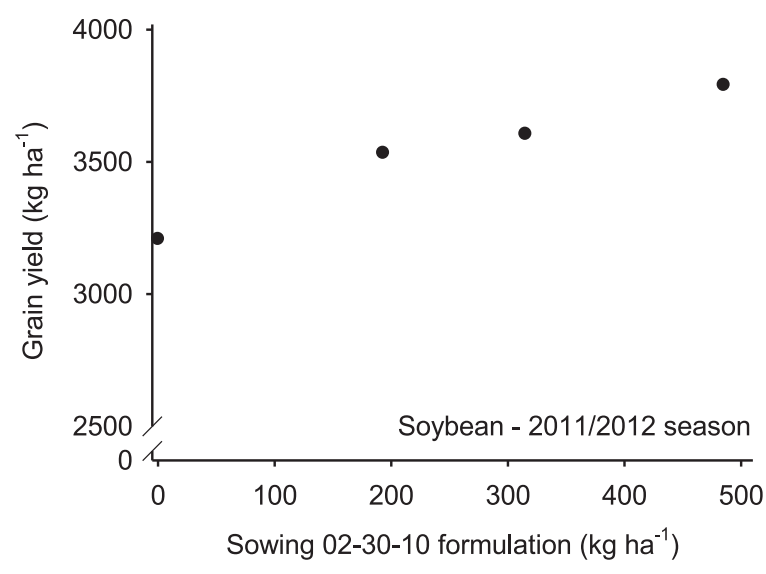

E.

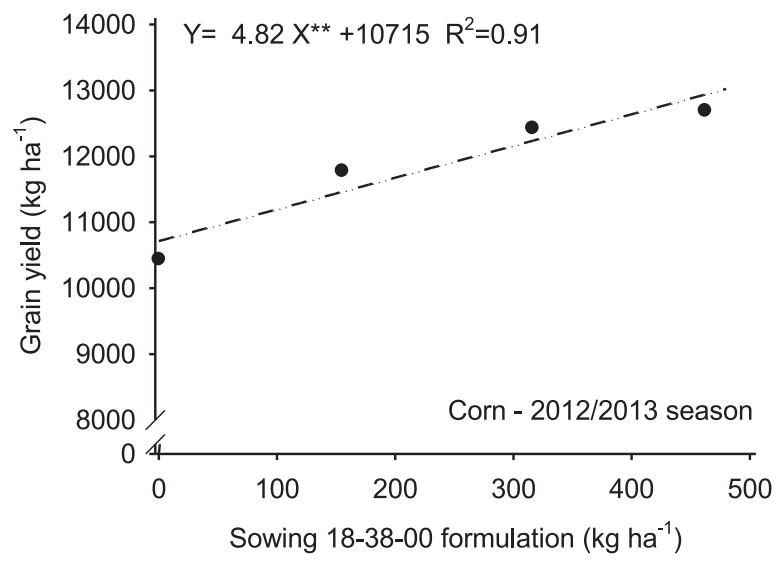

B.

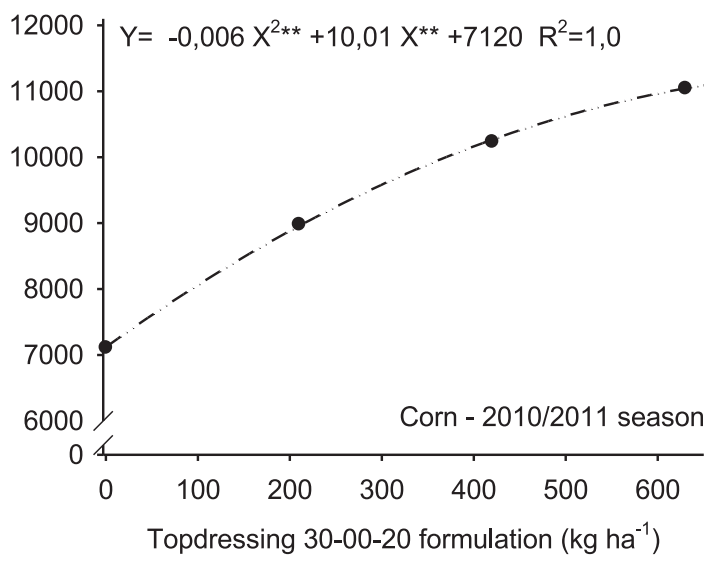

D.

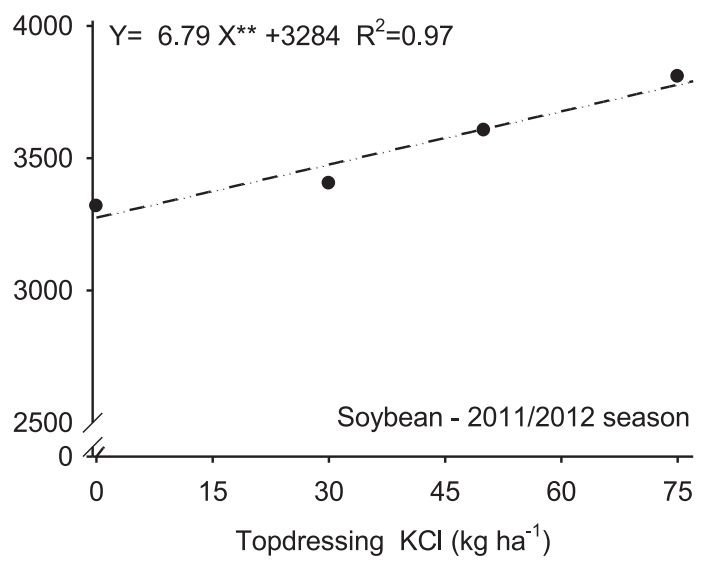

$\mathrm{F}$.

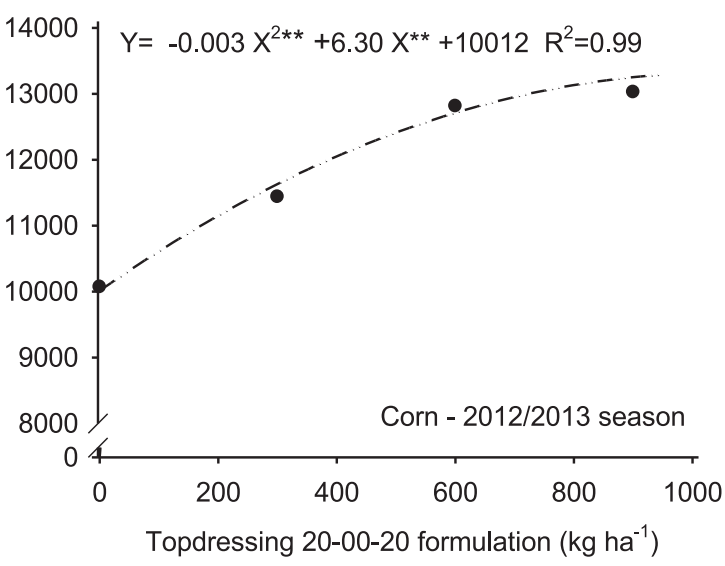


Source: Elaborated by the authors (2017)

According to the response to topdressing, the dose for maximum economic efficiency, corresponding to $90 \%$ of maximum yield, is $400 \mathrm{~kg} \mathrm{ha}^{-1}$ of NPK 30-00-20 fertilizer. The better response of corn to NK fertilization in topdressing indicates that phosphorus availability was the least limiting factor to that crop since the response to sowing fertilization starts with a yield of 8,608 $\mathrm{kg} \mathrm{ha}^{-1}$ (Figure 1A). Taking into account the good initial reserve of $P$ and $K$ in the soil (Table 1 ), which were above the critical levels established for annual crops (ALVAREZ et al., 1999; SOUSA; LOBATO; REIN, 2004; VILELA; SOUSA; SILVA, 2004), it can be inferred that nitrogen was the nutrient that most contributed to corn yield gains with fertilization.

In the second crop (soybean), no significant effect was observed for sowing fertilization. However, yield gain was observed with potassium applied as topdressing (Figures $1 \mathrm{C}$ and 1D). Grain yield varied between 3,032 and 4,098 $\mathrm{kg} \mathrm{ha}^{-1}$, depending on the treatment, which is well above the Brazilian average of $2.600 \mathrm{~kg} \mathrm{ha}^{-1}$ estimated for that crop (CONAB, 2013).

The lack of response of soybeans to sowing fertilization is owing to the greater rusticity of this crop when compared with corn. In this way, the former is less sensitive to differences in nutrient availability (AMADO et al., 2007), presenting lower yield variation due to fertilization treatments. This behavior is reasonable when considering that the clayey soil (58 dag $\mathrm{kg}^{-1}$ clay) of the experimental area, which had been used in no-tillage systems, and fertilized for many years, must present a high degree of buffering, which was favorable to the conservation of high levels of nutrients and organic matter at the beginning of the experiment (Table 1). The buffering might also contribute to increasing fertilizer use efficiency (CUBILLA et al., 2007; RESENDE et al., 2012) so that moderate doses are sufficient to meet the demand for a soybean crop in this soil with improved fertility.

Similarly to the first crop, a linear response of corn to sowing fertilization and quadratic response to topdressing was observed in the 2012/2013 agricultural year (Figures $1 \mathrm{E}$ and $1 \mathrm{~F}$ ), and the fertilizer used at sowing did not contain potassium. According to the model obtained in function of topdressing, $384 \mathrm{~kg} \mathrm{ha}^{-1}$ of the fertilizer used correspond to the dose for maximum economic efficiency. Again, phosphorus appears as the least limiting nutrient since yield was close to 10,500 $\mathrm{kg} \mathrm{ha}^{-1}$ in the absence of sowing fertilization.

Corn yield in the 2012/2013 agricultural year was higher than in the 2010/2011 agricultural year, varying from 8,496 to $13,898 \mathrm{~kg} \mathrm{ha}^{-1}$ according to the treatment. Even in the treatment that did not receive fertilization for three sequential crops, 2,686 $\mathrm{kg} \mathrm{ha}^{-1}$ more grains were produced in relation to the first corn crop. Since high productive potential hybrids were used, this difference in yield is due to the combined effect of factors that favored the second crop, such as the best final stand and the introduction of soybean rotation in the 2011/2012 agricultural year. The final stand was estimated at 73,000 plants ha-1 in the 2010/2011 agricultural year, and at 75,000 in the 2012/2013 agricultural year. The use of rotation with soybean with a history of successive corn crops certainly contributed to increasing the productive potential in that environment. The benefits of crop rotation and no-tillage in grain production have been intensively described in the literature (LOPES et al., 2004), mainly regarding the benefits of biological activity and greater buffering in nutrient dynamics and availability. The use of soybeans in a rotation system promotes corn yield gains by providing higher $\mathrm{N}$ uptake to the system due to the biological nitrogen fixation, and subsequent straw mineralization (ALVES et al., 2006).

Considering the yield cumulative data and the total $\mathrm{N}$ inputs in the different combinations of sowing fertilization and topdressing treatments, the adjusted model allowed estimating a maximum 
grain yield of $29,850 \mathrm{~kg} \mathrm{ha}^{-1}$ in the three crops (Figure $2 \mathrm{~A}$ ). The $\mathrm{N}$ dose associated with the maximum technical efficiency was $716 \mathrm{~kg} \mathrm{ha}^{-1}$, while the $\mathrm{N}$ dose associated with the maximum economic efficiency, corresponding to $90 \%$ of maximum yield, was estimated at $356 \mathrm{~kg} \mathrm{ha}^{-1}$. Since there is no need to apply nitrogen in soybean crops, it can be assumed that the economic dose for the corn/ soybean/corn system in the studied field is equivalent to the supply of $178 \mathrm{~kg} \mathrm{ha}^{-1}$ of $\mathrm{N}$ to each corn crop. This dose is consistent with that suggested by Resende et al. (2012), who recommend the use of 150 to $210 \mathrm{~kg} \mathrm{ha}^{-1}$ of $\mathrm{N}$ for a corn yield expectation between 10,000 and $12,000 \mathrm{~kg} \mathrm{ha}^{-1}$, which is a range that includes the maximum economic yield of 10,166 and $11,988 \mathrm{~kg}^{-1}$ estimated in the present study for the agricultural years of 2010/2011 and 2012/2013, respectively.

A maximum yield of $30,377 \mathrm{~kg} \mathrm{ha}^{-1}$ was estimated for the response to the cumulative potassium supplied as sowing fertilization and topdressing in the three crops (Figure 2B). The $\mathrm{K}_{2} \mathrm{O}$ dose for maximum economic efficiency in the system is $387 \mathrm{~kg} \mathrm{ha}^{-1}$, corresponding to the mean application of $129 \mathrm{~kg} \mathrm{ha}^{-1}$ in each crop (corn/soybean/corn). This optimum amount of potassium estimated for the system corroborates the recommendations reported in the literature. Resende et al. (2012) suggest the use of 140 to $170 \mathrm{~kg} \mathrm{ha}^{-1}$ of $\mathrm{K}_{2} \mathrm{O}$ for a corn yield between 12,000 and $14,000 \mathrm{~kg} \mathrm{ha}^{-1}$ in soils with $\mathrm{K}$ levels close to $80 \mathrm{mg} \mathrm{dm}^{-3}$. In the soybean crop, Sousa and Lobato (2004) recommend applying between 40 and $50 \mathrm{~kg} \mathrm{ha}^{-1}$ of $\mathrm{K}_{2} \mathrm{O}$ for the initial availability of $\mathrm{K}$ above $80 \mathrm{mg} \mathrm{dm}^{-3}$, which would result in a grain yield between 3,000 and 4,000 $\mathrm{kg} \mathrm{ha}^{-1}$.

Figure 2. Cumulative grain yield of corn/soybean/corn crops in function of cumulative $N$ doses $(A)$ and $K_{2} O$ doses (B) applied to the system. DMTE = dose for maximum technical efficiency; DMEE = dose for maximum economic efficiency. ${ }^{* *}$ Significant at $1 \%$ probability.

A.

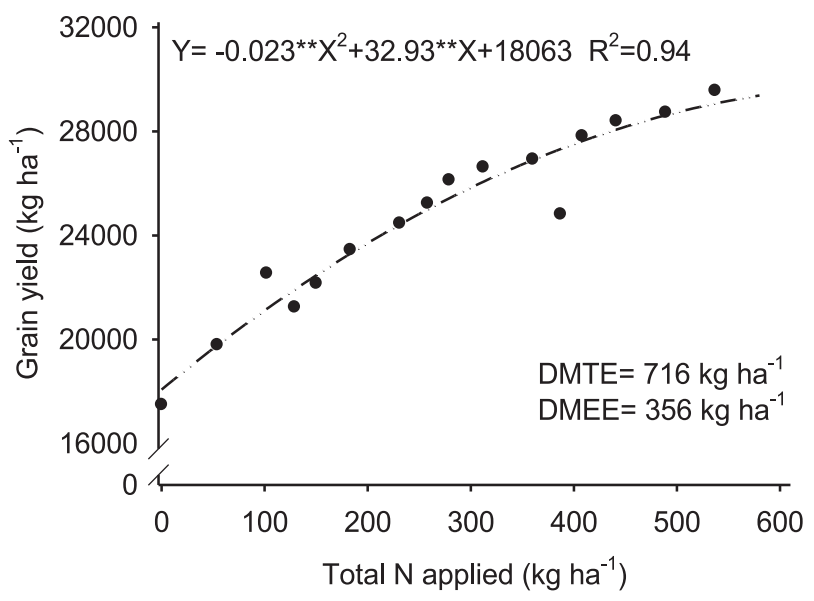

B.

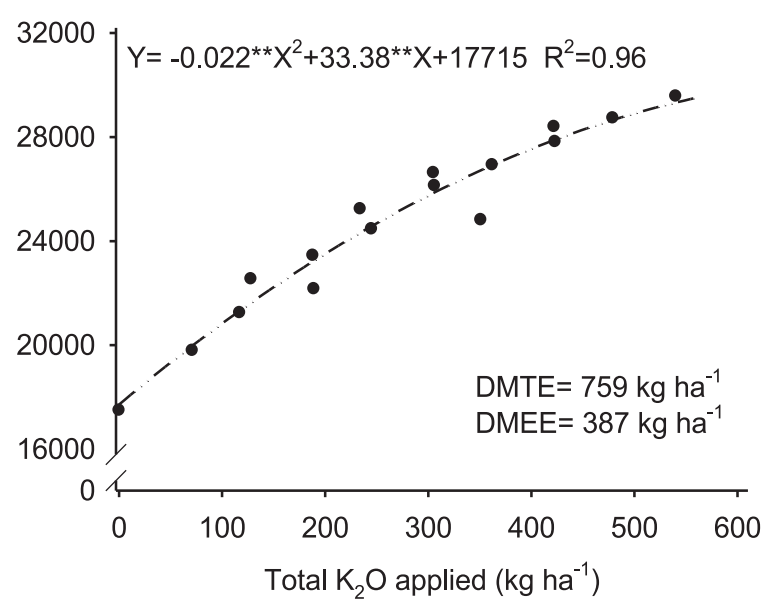

Source: Elaborated by the authors (2017)

Since phosphorus was supplied only as sowing fertilization, the cumulative response model was based on only four doses, presenting a linear adjustment for yield in function of the $\mathrm{P}$ supply ( $\mathrm{Y}=$ $8.4 * * X+22,507 ; R^{2}=0.96$ ). Despite being linear, the response to phosphorus starts with a grain yield of $22,507 \mathrm{~kg} \mathrm{ha}^{-1}$, contrasting with the standard response identified for $\mathrm{N}$ and $\mathrm{K}$, whose absence in fertilization resulted in higher yield of 18,063 and $17,715 \mathrm{~kg} \mathrm{ha}^{-1}$, respectively (Figure 2). Thus, $\mathrm{N}$ and $\mathrm{K}$ supplies were more critical to guarantee the productive potential of the growing environment during the experiment. This fact is certainly due to the history of $\mathrm{P}$ accumulation in the clayey soil, as a consequence of corrective and maintenance fertilization, creating a reserve that can significantly supply part of the crop's demand during some agricultural years. 
Due to the saturation of $\mathrm{P}$ adsorption sites with fertilizers applied over time, the intensity of the response to phosphate fertilization decreases in soils that have already reached adequate average levels of this nutrient, which is required in lesser amounts by the crops when compared with $\mathrm{N}$ and $\mathrm{K}$ (SOUSA; LOBATO; REIN, 2004; CERETA et al., 2005; GATIBONI et al., 2007). The P stock available in the soil depends on the initial and historical fertilization content, being favored in no-tillage soils, with crop rotation and organic matter maintenance or input (CUBILLA et al., 2007; COSTA et al., 2009). These factors increase the use efficiency of phosphate fertilizers, which can be recovered by the plant in up to $67 \%$ over the years (SOUSA; LOBATO; REIN, 2004).

In the economic evaluation, even without fertilizer application, the corn/soybean/corn rotation system in the studied field resulted in a profit greater than $\mathrm{R} \$ 3,600.00 \mathrm{ha}^{-1}$, without deducting the fixed costs (Table 4). Different proportions of $\mathrm{N}, \mathrm{P}_{2} \mathrm{O}_{5}$, and $\mathrm{K}_{2} \mathrm{O}$ resulted in similar profitability when compared with each other, but with distinct mean nutrient use efficiency. The cumulative application of fertilizers that generated the highest economic revenue in the system ( $R \$ 5,884.70$ ha $\left.^{-1}\right)$ corresponded to 443,189 , and $394 \mathrm{~kg} \mathrm{ha}^{-1}$ of $\mathrm{N}, \mathrm{P}_{2} \mathrm{O}_{5}$, and $\mathrm{K}_{2} \mathrm{O}$, respectively. This profit was $14.3 \%$ higher than that obtained for the standard fertilization used in the farm, with 360,330 and $305 \mathrm{~kg}$ ha $^{-1}$ of $\mathrm{N}, \mathrm{P}_{2} \mathrm{O}_{5}$, and $\mathrm{K}_{2} \mathrm{O}$. Comparing with the farm's management, the most profitable treatment involved increasing the amounts of $\mathrm{N}$ and $\mathrm{K}_{2} \mathrm{O}$ and reducing the amount of $\mathrm{P}_{2} \mathrm{O}_{5}$, which provided higher mean nutrient use efficiency. According to the doses applied to the crops (Table 2), $\mathrm{N} / \mathrm{P}_{2} \mathrm{O}_{5} / \mathrm{K}_{2} \mathrm{O}$ ratios of 1.0/0.3/0.8 and 0.1/1.0/1.1 were supplied to the corn and soybean crops, respectively. 
Table 4. Profitability and nutrient use efficiency (NUE) in the cumulative response to the supply of $\mathrm{N}, \mathrm{P}_{2} \mathrm{O}_{5}$, and $\mathrm{K}_{2} \mathrm{O}$ in the corn/soybean/corn rotation system.

\begin{tabular}{|c|c|c|c|c|c|c|c|c|c|c|}
\hline \multicolumn{3}{|c|}{ Nutrients applied } & \multirow{2}{*}{$\begin{array}{l}\text { Cumulative } \\
\text { yield }\end{array}$} & \multirow{2}{*}{$\operatorname{Cost}^{(1)}$} & \multirow{2}{*}{$\begin{array}{c}\text { Gross } \\
\text { revenue }^{(2)}\end{array}$} & \multirow{2}{*}{ Profit } & \multicolumn{4}{|c|}{$\operatorname{NUE}^{(3)}$} \\
\hline $\mathbf{N}$ & $\mathrm{P}_{2} \mathrm{O}_{5}$ & $\mathrm{~K}_{2} \mathrm{O}$ & & & & & $\mathbf{N}$ & $\mathrm{P}_{2} \mathrm{O}_{5}$ & $\mathrm{~K}_{2} \mathrm{O}$ & Mean \\
\hline \multicolumn{4}{|c|}{--------------- kg ha'1 --------------- } & \multicolumn{3}{|c|}{ 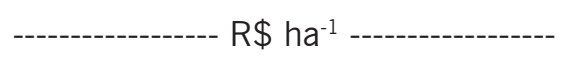 } & \multicolumn{4}{|c|}{ 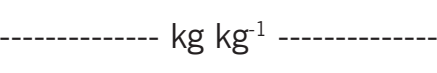 } \\
\hline 0 & 0 & 0 & 17,496 & $5,497.00$ & $9,167.60$ & $3,670.60$ & - & - & - & - \\
\hline 129 & 0 & 117 & 21,249 & $6,150.40$ & $10,561.36$ & $4,410.96$ & 29 & - & 32 & 20 \\
\hline 258 & 0 & 234 & 25,239 & $6,803.80$ & $12,321.24$ & $5,517.44$ & 30 & - & 33 & 21 \\
\hline 387 & 0 & 351 & 24,822 & $7,457.20$ & $12,200.00$ & $4,742.80$ & 19 & - & 21 & 13 \\
\hline 56 & 189 & 43 & 19,798 & $6,137.83$ & $10,136.00$ & $3,998.17$ & 41 & 12 & 54 & 36 \\
\hline 185 & 189 & 160 & 23,451 & $6,791.23$ & $11,760.40$ & $4,969.17$ & 32 & 32 & 37 & 34 \\
\hline 314 & 189 & 277 & 26,628 & $7,444.63$ & $13,044.12$ & $5,599.49$ & 29 & 48 & 33 & 37 \\
\hline 443 & 189 & 394 & 28,400 & $8,098.03$ & $13,982.76$ & $5,884.73$ & 25 & 58 & 28 & 37 \\
\hline 102 & 330 & 7 & 22,548 & $6,819.89$ & $11,291.76$ & $4,471.87$ & 50 & 15 & 71 & 45 \\
\hline 231 & 330 & 188 & 24,471 & $7,473.29$ & $12,141.88$ & $4,668.59$ & 30 & 21 & 37 & 29 \\
\hline 360 & 330 & 305 & 26,932 & $8,126.69$ & $13,275.20$ & $5,148.51$ & 26 & 29 & 31 & 29 \\
\hline 489 & 330 & 422 & 28,733 & $8,780.09$ & $14,174.44$ & $5,394.35$ & 23 & 34 & 27 & 28 \\
\hline 150 & 493 & 106 & 22,165 & $7,468.11$ & $11,235.80$ & $3,767.69$ & 31 & 9 & 44 & 28 \\
\hline 279 & 493 & 223 & 26,130 & $8,121.51$ & $12,918.36$ & $4,796.85$ & 31 & 18 & 39 & 29 \\
\hline 408 & 493 & 340 & 27,824 & $8,774.91$ & $13,816.96$ & $5,042.05$ & 25 & 21 & 30 & 25 \\
\hline 537 & 493 & 457 & 29,569 & $9,428.31$ & $14,614.24$ & $5,185.93$ & 22 & 24 & 26 & 24 \\
\hline
\end{tabular}

Corn - 2010/2011 agricultural year: price per kg of NPK 10-30-10 (sowing fertilization) $=\mathrm{R} \$ 1.31$; and NPK 30-00-20 (topdressing) $=\mathrm{R} \$ 1$ 1.24. Soybean - 2011/2012 agricultural year: price per kg of NPK 02-30-10 (sowing fertilization) $=\mathrm{R} \$ 1.21$; and $\mathrm{KCl}$ (topdressing) $=\mathrm{R} \$ 1.31$. Corn - 2012/2013 agricultural year: price per kg of NPK 18-38-00 (sowing fertilization) = R \$ 1.38; and NPK 22-00-20 (topdressing) $=\mathrm{R} \$ 1.20$. Final operational cost per hectare, without considering the costs with fertilizer used in the corn crop $=R \$ 1,964.00$ and soybean crop $=R \$ 1,569.00$. (2) Price of a $60 \mathrm{~kg}$ bag for corn $=R \$ 24.22$ and soybean $=R \$ 65.23$. (3) Nutrient use efficiency: NUE = (grain yield with the nutrient - grain yield without the nutrient)/amount of nutrient applied.

Source: Elaborated by the authors (2017)

In general, higher doses of fertilizers resulted in lower profitability and nutrient use efficiency (Table 4). Fertilization in the studied farm tended to supply phosphorus at doses above that necessary to meet the demand for the three crops evaluated. Conversely, an economic response was reported for the additional $\mathrm{N}$ and $\mathrm{K}$ supply. At the soil fertility condition of the studied field, it is certainly possible to improve NPK fertilizer management to reconcile greater profitability and fertilizer use efficiency. In the case of phosphorus and potassium, this possibility should be related to periodic monitoring with soil analysis, so that the available stocks in the system are not compromised. 


\section{Conclusions}

In soils with improved fertility, corn is more responsive to fertilization than soybeans; the highest grain yield gains are associated with $\mathrm{N}$ and $\mathrm{K}$ supply, whereas $\mathrm{P}$ is less limiting in a corn/soybean/ corn.

The most profitable combination of cumulative nutrient doses for the system involves increasing the $\mathrm{N}$ and $\mathrm{K}$ doses and reducing the $\mathrm{P}$ dose in relation to the farm's standard fertilization, providing a $14.3 \%$ higher profit and a higher mean nutrient use efficiency.

\section{Acknowledgment}

To FAPEMIG and CNPq, for the financial support and scholarships. To the owners and workers at Fazenda Santa Helena, for providing the experimental area and inputs, and for assisting in the experiment.

\section{Rentabilidade e eficiência da adubação em um sistema milho/ soja/milho em Latossolo de fertilidade construída}

\section{Resumo}

Atualmente existem dúvidas quanto ao dimensionamento da adubação visando altas produtividades de grãos em solos de fertilidade construída com sistemas de culturas rotacionadas. Neste sentido, objetivou-se avaliar a produtividade e a rentabilidade resultantes de diferentes combinações de adubação NPK e a eficiência de uso desses nutrientes em safras consecutivas de milho/soja/miIho, em um Latossolo de fertilidade construído em Fazenda dos Campos das Vertentes (MG). Foram comparados quatro níveis de adubação de semeadura e de cobertura, correspondendo a proporções aproximadas de 25, 50, 100 e $150 \%$ da dose normalmente aplicada pelo agricultor. As fontes de nutrientes variaram conforme os insumos empregados na fazenda a cada safra. Na condição de solo com fertilidade construída, o milho é mais responsivo à adubação do que a soja, sendo os maiores ganhos de produtividade de grãos associados ao fornecimento de $\mathrm{N}$ e K , enquanto o $\mathrm{P}$ mostra-se menos limitante. A combinação mais rentável de nutrientes para o sistema envolve incremento nas quantidades de $\mathrm{N}$ e $\mathrm{K}$ e redução no $\mathrm{P}$ em relação à adubação padrão da fazenda, proporcionando lucro 14,3\% superior e maior eficiência média de uso dos nutrientes fornecidos.

Palavras-chave: Uso eficiente de fertilizantes. Rotação de culturas. Alta produtividade de grãos. Agricultura de alto investimento.

\section{References}

ALMEIDA, J. D.; BERTOL, I.; LEITE, D.; AMARAL, A. D.; ZOLDAN JR, W. A. Propriedades químicas de um Cambissolo Húmico sob preparo convencional e semeadura direta após seis anos de cultivo. Revista Brasileira de Ciência do Solo, v. 29, n. 3, p. 437-445, 2005. Disponível em: <http://www. scielo.br/pdf/\%0D/rbcs/v29n3/25744.pdf>. Acesso em: 01 jul. 2016. 
ALMEIDA, V. P.; ALVES, M. C.; SILVA, E. C.; OLIVEIRA, S. P. Rotação de culturas e propriedades físicas e químicas em latossolo vermelho de cerrado sob preparo convencional e semeadura direta em adoção. Revista Brasileira de Ciência do Solo, Viçosa, v. 32, n. 3, p. 1227-1237, 2008. Disponível em: <http://www.scielo.br/pdf/\%0D/rbcs/v29n3/25744.pdf>. Acesso em: 01 jul. 2016.

ALVAREZ, V. V. H.; NOVAIS, R. F.; BARROS, N. F.; CANTARUTTI, R. B.; LOPES, A. S. Interpretação dos resultados das análises de solo. In: RIBEIRO, A. C.; GUIMARÃES, P. T. G.; ALVAREZ V. V. H. Recomendações para o uso de corretivos e fertilizantes em Minas Gerais. $5^{a}$ aproximação. Viçosa, MG, 1999. p. 25-32.

ALVES, B. J. R.; ZOTARELLI, L.; FERNANDES, F. M.; HECKLER, J. C.; MACEDO, R. A. T.; BODDEY, R. M.; JANTALIA, C. P.; URQUIAGA, S. Fixação biológica de nitrogênio e fertilizantes nitrogenados no balanço de nitrogênio em soja, milho e algodão. Pesquisa Agropecuária Brasileira, Brasília, v. 41, n. 3, p. 449-456, 2006. Disponível em: <http://www.scielo.br/pdf/\%0D/pab/v41n3/29116.pdf>. Acesso em: 01 jul. 2016.

AMADO, T. J. C.; MIELNICZUK, J.; AITA, C. Recomendação de adubação nitrogenada para o milho no RS e SC adaptada ao uso de culturas de cobertura do solo, sob sistema plantio direto. Revista Brasileira de Ciência do Solo, Viçosa, v. 24, n. 1, p. 241-248, 2002. Disponível em: <http://sbcs. solos.ufv.br/solos/revistas/v26n1a25.pdf>. Acesso em: 01 jul. 2016.

AMADO, T. J. C.; PONTELLI, C. B.; SANTI, A. L.; VIANA, J. H. M.; SULZBACH, L. A. S. Variabilidade espacial e temporal da produtividade de culturas sob sistema plantio direto. Pesquisa Agropecuária Brasileira, Brasília, v. 42, n. 8, p. 1101-1110, 2007. Disponível em: <http://www.scielo.br/pdf/pab/ v42n8/a06v42n8.pdf>. Acesso em: 01 jul. 2016.

CERETTA, C. A; BASSO, C. J.; PAVINATO, P. S.; TRENTIN, E. E.; GIROTTO, E. Produtividade de grãos de milho, produção de matéria seca e acúmulo de nitrogênio, fósforo e potássio na rotação aveia preta/milho/nabo forrageiro com aplicação de dejeto líquido de suínos. Ciência Rural, Santa Maria, v. 35, n. 6, p. 1287-1295, 2005. Disponível em: <http://www.scielo.br/pdf/cr/v35n6/a10v35n6>. Acesso em: 01 jul. 2016.

CEPEA/ESALQ - Centro de Estudos Avançados em Economia Aplicada - Escola Superior de Agricultura Luiz de Queiróz. Disponível em: <http://www.cepea.esalq.usp.br/soja/>. Acesso em: 31 jul. 2013.

COMPANHIA NACIONAL DE ABASTECIMENTO (CONAB). Disponível em: <http://www.conab.gov. br>. Acesso em: 31 jan. 2014.

COSTA, S. E. V. G.; SOUZA, E. D. D.; ANGHINONI, I.; FLORES, J. P. C.; CAO, E. G.; HOLZSCHUH, M. J. Phosphorus and root distribution and corn growth as related to long-term tillage systems and fertilizer placement. Revista Brasileira de Ciência do Solo, Viçosa, v. 33, p.1237-1247, 2009. Disponível em: <http://www.scielo.br/pdf/rbcs/v33n5/v33n5a17.pdf>. Acesso em: 01 jul. 2016.

CUBILLA, M. M.; AMADO, T. J. C.; WENDLING, A.; ELTZ, F. L. F.; MIELNICZUK, J. Calibração visando à fertilização com fósforo para as principais culturas de grãos sob sistema plantio direto no Paraguai. Revista Brasileira de Ciência do Solo, Viçosa, v. 31, n. 6, p. 1463-1474, 2007. Disponível em: <http://www.scielo.br/pdf/rbcs/v31n6/23.pdf>. Acesso em: 01 jul. 2016. 
FAGERIA, N. K.; SANTOS, A. B.; CUTRIM, V. A. Produtividade de arroz irrigado e eficiência de uso do nitrogênio influenciadas pela fertilização nitrogenada. Pesquisa Agropecuária Brasileira, Brasília, v. 42, n. 7, p. 1029-1034, 2007. Disponível em: <http://www.scielo.br/pdf/\%0D/pab/v42n7/16. pdf>. Acesso em: 01 jul. 2016.

FERREIRA, D. F. Sisvar: a computer statistical analysis system. Ciência e Agrotecnologia, Lavras, v. 35, n. 6, p. 1039-1042, 2011. Disponível em: <http://www.scielo.br/pdf/cagro/v35n6/a01v35n6. pdf $>$. Acesso em: 01 jul. 2016.

GATIBONI, L. C.; KAMINSKI, J.; RHEINHEIMER, D. D. S.; FLORES, J. P. C. Biodisponibilidade de formas de fósforo acumuladas em solo sob sistema plantio direto. Revista Brasileira de Ciência do Solo, v. 31, n. 4, p. 691-699. 2007. Disponível em: <http://www.scielo.br/pdf/rbcs/v31n4/ a10v31n4.pdf>. Acesso em: 01 jul. 2016.

KATSVAIRO, T. W.; COX, W. J. Tillage x rotation x management interactions in corn. Agronomy Journal, v. 92, n. 3, p. 493-500, 2000. Disponível em: <https://dl.sciencesocieties.org/publications/aj/ abstracts/92/3/493>. Acesso em: 01 jul. 2016.

LOPES, A. S.; WIETHOLTER, S.; QUILHERME, L. R. G.; SILVA, C. A. Sistema plantio direto: bases para o manejo da fertilidade do solo. São Paulo: Associação Nacional para Difisão de Adubos - ANDA, 2004. 110p.

PAULETTI, V.; SERRAT, B. M.; MOTTA, A. C. V.; FAVARETTO, N.; ANJOS, A. D. Yield response to fertilization strategies in no-tillage soybean, corn and common bean crops. Brazilian Archives of Biology and Technology, v. 53, n. 3, p. 563-574, 2010. Disponível em: <http://www.scielo.br/pdf/ babt/v53n3/a09v53n3.pdf>. Acesso em: 01 jul. 2016.

RESENDE, A. V.; COELHO, A. M.; SANTOS, F. C.; LACERDA, J. J. J. Fertilidade do solo e manejo da adubação NPK para alta produtividade de milho no Brasil Central. Sete Lagoas: Embrapa Milho e Sorgo, 2012. 12p. Circular Técnica, n. 181, Disponível em: <http://www.infoteca.cnptia.embrapa. br/bitstream/doc/951901/1/circ181.pdf>. Acesso em: 01 jul. 2016.

SANTOS, L. P. D.; AQUINO, L. A.; NUNES, P. H. M. P.; XAVIER, F. O. Doses de nitrogênio na cultura do milho para altas produtividades de grãos. Revista Brasileira de Milho e Sorgo, Sete Lagoas, v. 12, n. 3, p. 270-279, 2013. Disponível em: <http://rbms.cnpms.embrapa.br/index.php/ojs/article/ view/449/pdf_76>. Acesso em: 01 jul. 2016.

SILVA, F. C. da (Ed.). Manual de análises químicas de solos, plantas e fertilizantes. 2. ed. Brasília: Embrapa Informação Tecnológica; Rio de Janeiro: Embrapa Solos, 2009. 627p.

SOUSA, D. M. G.; LOBATO, E. Calagem e adubação para culturas anuais e semiperenes. In: SOUSA, D. M. G.; LOBATO, E. (Eds.). Cerrado: Correção do solo e adubação. 2 ed. Brasília, DF: Embrapa Informação Tecnológica, 2004. p. 283-315.

SOUSA, D. M. G.; LOBATO, E.; REIN, T. Adubação com fósforo. In: SOUSA, D. M. G.; LOBATO, E. (Eds.). Cerrado: Correção do solo e adubação. 2 ed. Brasília, DF: Embrapa Informação Tecnológica, 2004. p. 147-168. 
STANGER, T. F.; LAUER, J. G. Corn grain yield response to crop rotation and nitrogen over 35 years all. Agronomy Journal, v. 100, n. 3, p. 643-650, 2008. Disponível em: <https://dl.sciencesocieties. org/publications/aj/abstracts/100/3/643>. Acesso em: 01 jul. 2016.

TORRES, J. L. R.; PEREIRA, M. G.; FABIAN, A. J. Produção de fitomassa por plantas de cobertura e mineralização de seus resíduos em plantio direto. Pesquisa Agropecuária Brasileira, v. 43, n. 3, p. 421-428, 2008. Disponível em: <http://www.scielo.br/pdf/pab/v43n3/a18v43n3.pdf>. Acesso em: 01 jul. 2016.

VILELA, L.; SOUSA, D. M. G.; SILVA, J. E. Adubação potássica. In: SOUSA, D. M. G.; LOBATO, E. (Eds.). Cerrado: Correção do solo e adubação. 2 ed. Brasília, DF: Embrapa Informação Tecnológica, 2004. p. 169-183.

WENDLING, A.; ELTZ, F. L. F.; CUBILLA, M. M.; AMADO, T. J. C.; MIELNICZUK, J. Recomendação de adubação potássica para trigo, milho e soja sob sistema plantio direto no Paraguai. Revista Brasileira de Ciência do Solo, Viçosa, v. 32, n. 5, p. 1929-1939, 2008. Disponível em: <http://www. scielo.br/pdf/rbcs/v32n5/14.pdf>. Acesso em: 01 jul. 2016.

\section{Histórico editorial:}

Submetido em: 01/07/2016.

Aceito em: 20/12/2016.

Como citar:

$\underline{A B N T}$

HICKMANN, C.; RESENDE, A. V. de; SILVA, C. A.; LACERDA, J. J. J.; MOREIRA, S. G.; CONCEIÇÃO, O. P. Profitability and efficiency of fertilization in a corn/soybean/corn system in a Latosol with improved fertility.

Revista Agrogeoambiental, Pouso Alegre, v. 9, n. 4, p. 97-110, out./dez.

Doi: http://dx.doi.org/10.18406/2316-1817v9n420171037

$\underline{A P A}$

HICKMANN, C., RESENDE, A. V. de, SILVA, C. A., LACERDA, J. J. J., MOREIRA, S. G. \& CONCEIÇÃO, O. P. (2017). Profitability and efficiency of fertilization in a corn/soybean/corn system in a Latosol with improved fertility. Revista Agrogeoambiental, 9 (4), 97-110.

Doi: http://dx.doi.org/10.18406/2316-1817v9n420171037

$\underline{\mathrm{ISO}}$

HICKMANN, C.; RESENDE, A. V. de; SILVA, C. A.; LACERDA, J. J. J.; MOREIRA, S. G. e CONCEIÇÃO, O. P. Profitability and efficiency of fertilization in a corn/soybean/corn system in a Latosol with improved fertility. Revista Agrogeoambiental, 2017, vol. 9, n. 4, pp. 97-110. Eissn 2316-1817.

Doi: http://dx.doi.org/10.18406/2316-1817v9n420171037

\section{VANCOUVER}

Hickmann C, Resende AV de, Silva CA, Lacerda JJJ, Moreira SG, Conceição OP. Profitability and efficiency of fertilization in a corn/soybean/corn system in a Latosol with improved fertility. Rev agrogeoambiental. 2017 out/dez; 9(4): 97-110. Doi: http://dx.doi.org/10.18406/2316-1817v9n420171037 